\title{
Tissue-specific effect of recombinant porcine growth hormone on expression of growth-related genes in the pig*
}

\author{
R.Q. Zhao, J. Zhou, Q.F. Xu, Z.H. Zhao, X.H. Wei, D. Xia, \\ W.H. Chen and J.Chen ${ }^{1}$
}

Key Laboratory of Animal Physiology and Biochemistry, Nanjing Agricultural University Nanjing 210095, P. R. China

(Received 20 January 2003; revised version 24 May 2003; accepted 15 July 2003)

\begin{abstract}
Sixteen castrated male Large White $\times$ Landrace pigs were injected intramuscularly with recom-

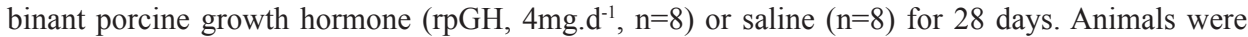
slaughtered $4 \mathrm{~h}$ after the final injection for tissue and blood sampling. RIA and semi-quantitative RT-PCR were employed for determining hormone and mRNA contents, respectively. rpGH administration enhanced average daily weight gain by $26.07 \%(\mathrm{P}<0.05)$, elevated serum IGF-I concentration by $70.94 \%(\mathrm{P}<0.01)$ but decreased serum level of leptin by $34.52 \%(\mathrm{P}<0.01)$. The relative abundance of GH-R mRNA was increased by $24.45 \%(\mathrm{P}<0.05)$ in liver, $50.66 \%(\mathrm{P}<0.05)$ in adipose tissue, $21.29 \%(\mathrm{P}<0.05)$ in semitendinosus $(\mathrm{ST})$, but not in longissimus dorsi (LD) muscle. Coordinately, IGF-1 mRNA expression was enhanced by $45.30 \%(\mathrm{P}<0.01)$ in liver, $27.82 \%(\mathrm{P}<0.05)$ in adipose tissue, $41.04 \%(\mathrm{P}<0.05)$ in ST, but not in LD muscle. The IGF-1 content in liver and ST were increased 2.97 and 5.53-fold, respectively. A significant (2.93-fold) increase of IGF-1 content was found in LD muscle too, uncoupling with the change in mRNA level. Moreover, rpGH administration augmented IGF-IR mRNA expression by $48.08 \%(\mathrm{P}<0.01)$ whereas abated leptin mRNA expression by $28.19 \%(\mathrm{P}<0.05)$ in adipose tissue. These results suggest that the effect of rpGH on GH-R and IGF-I gene expression is tissue-specific and rpGH administration may down-regulate leptin mRNA expression in adipose tissue either directly or via the mediation of local IGF-I/IGF-IR system.
\end{abstract}

KEY WORDS: pigs, GH, IGF-1, growth hormone receptor (GH-R), leptin, gene expression

\footnotetext{
*Supported by National Natural Science Foundation of China, No. 39830290

${ }^{1}$ Corresponding author: e-mail address: lapb@njau.edu.cn
} 


\section{INTRODUCTION}

Growth hormone (GH) plays an important role in regulation of animal growth. Numerous studies have shown that exogenous GH can increase average daily weight gain, improve feed efficiency, stimulate protein deposition and decrease lipid accretion rate (Etherton and Bauman, 1998). The original somatomedin hypothesis suggested that GH interact with hepatic GH-R and stimulate hepatic production of IGF-1 that is essential for normal growth and development (Florini et al., 1996). However, this hypothesis was challenged by the recent results gleaned from a liver-specific IGF-I gene knockout mouse model, which enabled investigators to re-evaluate the role of liver-derived IGF-I and circulating IGF-I on postnatal growth and development. It was surprising that despite $75 \%$ of reduction in serum IGF-I concentration, the liver-specific IGF-I-knockout mice were born with normal body weight and grew at a normal rate (Siogren, 1999; Yakar, 1999; Roith et al., 2001), suggesting an endocrine IGF-I independent pathway of growth regulation. Therefore, the autocrine and/or paracrine fashion of IGF-I action is proposed to play a more important role in growth regulation.

It is well established that adipose tissue represents an important target tissue for GH. Administration of GH to growing pigs reduced adipose tissue mass (Chung et al., 1985; Campbell et al.,1989). The effects of pGH on lipogenesis appear to be a direct action because essentially all effects that occur with in vivo pGH treatment can be mimicked when adipose tissue explants are cultured chronically with $\mathrm{pGH}$, whereas administration of insulin-like growth factor I for $28 \mathrm{~d}$ did not mimic the effects of pGH administration on carcass composition in pigs (Etherton, 2000). However, pGH administration significantly increased IGF-1 mRNA expression in subcutaneous adipose tissue (Coleman et al., 1994; Brameld et al., 1996). Treatment with pGH or IGF-I resulted in a similar decrease in proliferation of preadipocytes from Large White and Meishan pigs in primary culture (Gerfault et al., 1999). Although adipose tissue possesses both GH-R and IGF-IR, no response of GH-R mRNA to GH administration was found in adipose tissue (Brameld et al., 1996). The response of IGF-IR mRNA expression to $\mathrm{pGH}$ administration has not been reported, much less is known about the relationships among GH-R, IGF-IR and leptin expressed in adipose tissues and their coordinated response to $\mathrm{GH}$ administration.

Leptin is a protein encoded by ob gene, and can serve as an endocrine marker for total body fat deposition. More and more data are emerging to indicate that leptin is involved in the regulation of many physiological functions. The interactions between leptin and GH/IGF-1 axis have been discussed (Wauters et al., 2000). There are evidences that leptin is involved in the regulation of GH secretion, whether leptin secretion is also influenced by GH is not yet clear.

Therefore, the present study was aimed to elucidate the mechanisms underlying the action of rpGH on growth and adiposity through examination of growth-related genes responding to rpGH administration in the pig. 


\section{MATERIAL AND METHODS}

\section{Material}

Recombinant porcine growth hormone (rpGH) was obtained from Shenzhen Lupeng Agricultural Hi-tech Co. Ltd. (P.R. China). IGF-I peptide (catalog no. 810288, Cida-Geigy, Switzerland) was donated by Dr. H. H. Peter and IGF-I antibody was a gift from Prof. Louis E. Underwood, Bucknell University (USA). IGF-I was iodinated in Shanghai Institute of Biotechnology. Leptin RIA kit was purchased from Beijing North Institute of Biotechnology. The avian myeloblastosis virus (AMV) reverse transcriptase, Taq DNA polymerase and other related reagents were products of Promega (USA). Agarose was a product of Roche Applied Science (Switzerland; catalog no. 1441). The Quantum RNA 18S Internal Standards kit (catalog no. 1716) containing primers and competimers were purchased from Ambion Inc. Austin, Texas (USA).

\section{Animals and experimental design}

Sixteen castrated male Large White $\times$ Landrace pigs with average initial body weight of $50.8 \mathrm{~kg}$ (from 48 to $55 \mathrm{~kg}$ ) were housed individually in floor pens and fed according to the Breed Standards of USA (NRC, 1998). Pigs were randomly allotted to treatment or control group. The treatment group was injected intramuscularly with recombinant porcine growth hormone (rpGH, $4 \mathrm{mg}^{-1}$ ) and the control group with vehicle at 09.00 for 28 days. Animals were slaughtered $4 \mathrm{~h}$ after the final injection. Blood and samples of liver, longissimus dorsi (LD) and semitendinosus (ST) muscles and subcutaneous adipose tissue were taken immediately (within 5-10 min of death). Tissue samples were frozen in liquid nitrogen and then stored at $-70^{\circ} \mathrm{C}$. Serum was prepared and stored at $-20^{\circ} \mathrm{C}$. The experiment was undertaken following the guidelines of the regional Animal Ethics Committee.

\section{Radioimmunoassay for serum IGF-I and leptin}

Serum and total tissue IGF-I were measured by a double-antibody RIA as previously described by Liu et al. (1999) after acid-ethanol extraction to disassociate bound IGF-I from binding protein(s). Serum leptin level was determined by single-antibody RIA with a commercial kit. Bradford (1976) assay was employed to determine the tissue protein content.

\section{RNA extraction}

Total RNA was extracted from the tissue samples with acid guanidinium thiocyanate-phenol-chloroform method (Chomczynski and Sacchi, 1987) and the RNA 
concentration was then quantified by measuring the absorbance at $260 \mathrm{~nm}$ and the quality of RNA was examined through $1.4 \%$ agarose-formaldehyde gel electrophoresis.

Reverse transcription (RT) and polymerase chain reaction (PCR)

$2 \mu \mathrm{g}$ total RNA was reverse transcribed by incubation at $42^{\circ} \mathrm{C}$ for $1 \mathrm{~h}$ in a $20 \mu 1$ mixture consisting of $10 \mathrm{U}$ avian myeloblastosis virus reverse transcriptase, 20U RNase inhibitor, $5 \mu \mathrm{mol}$ random primers, $50 \mathrm{mmol}$ tris- $\mathrm{HCl} 1^{-1}$ (pH 8.3), 10 mmol $\mathrm{MgCl}_{2} \mathrm{l}^{-1}, 50 \mathrm{mmol} \mathrm{KCl}^{-1}, 10 \mathrm{mmol}^{\mathrm{DDT}} \mathrm{l}^{-1}, 0.5 \mathrm{mmol}$ spermidine $1^{-1}$ and $0.5 \mathrm{mmol}$ each $\mathrm{dNTP} 1^{-1}$. The reaction were terminated by heating at $95^{\circ} \mathrm{C}$ for $5 \mathrm{~min}$ and quickly cooling on ice. $2 \mu \mathrm{l}$ (liver and adipose tissue sample) or $4 \mu \mathrm{l}$ (LD and ST samples) RT reaction mix was used for PCR in a final volume of $50 \mu \mathrm{l}$ containing $0.1 \mathrm{U}$ Taq DNA polymerase $\mu \mathrm{l}^{-1}, 5 \mathrm{mmol}$ tris- $\mathrm{HCl} \mathrm{l}^{-1}$ (pH 9.0), $10 \mathrm{mmol} \mathrm{NaCl} \mathrm{l}^{-1}, 0.1 \mathrm{mmol}^{\mathrm{DDT} \mathrm{l}} \mathrm{l}^{-1}, 0.01 \mathrm{mmol}^{\mathrm{EDTA} \mathrm{l}} \mathrm{l}^{-1}, 5 \%$ (w/v) glycerol, $0.1 \%(\mathrm{w} / \mathrm{v})$ Triton X-100, $0.2 \mathrm{~mol}$ each $\mathrm{dNTP} 1^{-1}, 1.0-2.0 \mathrm{~mol} \mathrm{MgCl}_{2}$ $1^{-1}, 0.5 \mu \mathrm{mol}$ each of PCR primers for GH-R or IGF-I $1^{-1}$, and $0.4 \mu \mathrm{mol}$ mixture of primers for $18 \mathrm{~S}$ rRNA internal standard and competimer $1^{-1}$. The PCR primers for GH-R, IGF-I, IGF-IR and leptin were designed using Primer Premier 5.0 and were synthesized by Haojia Biotech. Ltd. The nucleotide sequences of these primers were shown in Table 1. Different controls were set to monitor the possible contaminations of genomic DNA and environment DNA both at the stage of RT and PCR. The pooled samples made by mixing equal quantity of total RNA from all samples were used for optimizing the PCR condition and normalizing the intra-assay variations. All samples were included in the same run of RT-PCR and repeated at least for 3 times.

TABLE 1

Nucleotide sequences of PCR primers for GH-R, IGF-I, IGF-IR and leptin

\begin{tabular}{|c|c|c|c|c|}
\hline $\begin{array}{l}\text { Target } \\
\text { gene }\end{array}$ & $\begin{array}{c}\text { cDNA } \\
\text { sequence }\end{array}$ & $\begin{array}{c}\text { PCR } \\
\text { product }\end{array}$ & Primer sequence & $\begin{array}{c}\text { PCR } \\
\text { program }\end{array}$ \\
\hline pGH-R & $\begin{array}{l}\text { Gene bank } \\
\text { X54429 }\end{array}$ & $\begin{array}{l}344 \\
(1059-1405)\end{array}$ & $\begin{array}{l}\text { F: 5'-CTCGATATTGATGACCCTGA-3' } \\
\text { R: 5'-GATGAGTTGAGTCAGTTCCA-3' }\end{array}$ & $\begin{array}{l}94^{\circ} \mathrm{C} 30 \mathrm{~s}, 52^{\circ} \mathrm{C} \\
30 \mathrm{~s}, 72^{\circ} \mathrm{C} 60 \mathrm{~s}\end{array}$ \\
\hline pIGF-1 & $\begin{array}{l}\text { Gene bank } \\
\text { AB00362 }\end{array}$ & $\begin{array}{l}222 \\
(255-457)\end{array}$ & $\begin{array}{l}\text { F: 5'-GGAGCTGTGATCTGAGGA-3' } \\
\text { R: 5'-ACAGTAACCTCGTGCAGA-3' }\end{array}$ & $\begin{array}{l}94^{\circ} \mathrm{C} 30 \mathrm{~s}, 56^{\circ} \mathrm{C} \\
30 \mathrm{~s}, 72^{\circ} \mathrm{C} 60 \mathrm{~s}\end{array}$ \\
\hline pIGF-1R & $\begin{array}{l}\text { Gene bank } \\
\text { M31175 }\end{array}$ & $\begin{array}{l}362 \mathrm{bp} \\
(3497-3859)\end{array}$ & $\begin{array}{l}\text { F: 5'-CGAGAGACATCTATGAGACA-3' } \\
\text { R: 5'-TCCTCACTGTAGTAGAAGGA -3' }\end{array}$ & $\begin{array}{l}94^{\circ} \mathrm{C} 30 \mathrm{~s}, 52^{\circ} \mathrm{C} \\
30 \mathrm{~s}, 72^{\circ} \mathrm{C} 60 \mathrm{~s}\end{array}$ \\
\hline pLeptin & $\begin{array}{l}\text { Gene bank } \\
\text { U59894 }\end{array}$ & $\begin{array}{l}253 \mathrm{bp} \\
(22-274)\end{array}$ & $\begin{array}{l}\text { F: 5'-CGATTCCTGTGGCTTTGG -3' } \\
\text { R: 5'-TGGAAGGCAGACTGGTGAG -3' }\end{array}$ & $\begin{array}{l}94^{\circ} \mathrm{C} 30 \mathrm{~s}, 52^{\circ} \mathrm{C} \\
30 \mathrm{~s}, 72^{\circ} \mathrm{C} 60 \mathrm{~s}\end{array}$ \\
\hline
\end{tabular}




\section{Quantitation of PCR products and statistical analysis}

An aliquot (10-20 $\mu 1)$ of PCR products was analyzed by electrophoresis on $2 \%$ agarose gels. The gel was stained with ethidium bromide and photographed with digital camera. The net intensities of individual bands were measured using Kodak Digital Science 1D software (Eastman Kodak Company Rochester, NY, USA).

The $18 \mathrm{~S}$ primer pair amplifies a $488 \mathrm{bp}$ fragment, and the competimers are modified at their 3' ends to block the extension of DNA. By adjusting the ratio of $18 \mathrm{~S}$ primers to competimers, the overall PCR amplification efficiency of $18 \mathrm{~S}$ rRNA can be reduced to the level comparable to that of target gene. The ratios of net intensity of target genes to $18 \mathrm{~S}$ bands were used to represent the relative level of target gene expression. The average level of three repeats was used for statistical analysis. All data were expressed as mean \pm S.E.M. Differences were considered significant when $\mathrm{P}<0.05$ tested by ANOVA with STATISTICA for Windows 5.0 (StatSoft, Inc.).

\section{RESULTS}

\section{Body weight}

The initial and final body weights of pigs were $50.5 \pm 3.5 \mathrm{~kg}$ and $71.5 \pm 5.1 \mathrm{~kg}$ in rpGH treatment group, $51.2 \pm 4.5 \mathrm{~kg}$ and $67.8 \pm 5.0 \mathrm{~kg}$ in control group, respectively. Administration of rpGH enhanced the average daily weight gain by $26.1 \%$ $(\mathrm{P}<0.05$; Table 2).

TABLE 2

Effect of rpGH administration on serum concentrations of IGF-I and leptin

\begin{tabular}{lccc}
\hline & $\begin{array}{c}\text { Daily body weight gain } \\
\mathrm{g} / \mathrm{d}\end{array}$ & $\begin{array}{c}\text { Serum IGF-I } \\
\text { ng.mL } \mathrm{mL}^{-1}\end{array}$ & $\begin{array}{c}\text { Serum leptin } \\
\text { ng.mL } \mathrm{mL}^{-1}\end{array}$ \\
\hline Control & $594.6 \pm 17.3$ & $74.15 \pm 7.77$ & $1.68 \pm 0.06$ \\
rpGH treatment & $749.6 \pm 31.5^{*}$ & $126.75 \pm 25.17^{* *}$ & $1.10 \pm 0.03^{* *}$ \\
\hline
\end{tabular}

$* \mathrm{P}<0.05, * * \mathrm{P}<0.01$ compared with control

\section{Serum levels of IGF-I and leptin}

rpGH administration increased serum concentration of IGF-I by $70.94 \%$ $(\mathrm{P}<0.01)$ while decreased leptin concentration by $34.8 \%(\mathrm{P}<0.01)$ compared to control group. 
GH-R and IGF-I mRNA expression in liver

GH administration up-regulated hepatic GH-R mRNA and IGF-I mRNA expression by $24.45 \%(\mathrm{P}<0.05)$ and $45.30 \%(\mathrm{P}<0.01)$, respectively (Table 3, Figure 1$)$.

TABLE 3

The relative mRNA abundance of target genes in liver, longissimus dorsi muscle(LD), semitendinosus muscle (ST) and adipose tissue of growing pigs in response to rpGH administration

\begin{tabular}{lccc}
\hline Tissue & Target mRNA & $\begin{array}{c}\text { Control } \\
\text { (relative to18S rRNA) }\end{array}$ & $\begin{array}{c}\text { rpGH treatment } \\
\text { (relative to18S rRNA) }\end{array}$ \\
\hline \multirow{2}{*}{ Liver } & GH-R & $1.333 \pm 0.033$ & $1.659 \pm 0.092^{*}$ \\
LD muscle & IGF-1 & $0.662 \pm 0.029$ & $0.961 \pm 0.064^{* *}$ \\
ST muscle & GH-R & $1.470 \pm 0.022$ & $1.617 \pm 0.013$ \\
& IGF-1 & $0.736 \pm 0.049$ & $0.840 \pm 0.056$ \\
Adipose tissue & GH-R & $0.785 \pm 0.045$ & $0.955 \pm 0.050^{*}$ \\
& IGF-1 & $1.115 \pm 0.135$ & $1.573 \pm 0.123^{* *}$ \\
& GH-R & $0.529 \pm 0.038$ & $0.797 \pm 0.023^{*}$ \\
& IGF-1 & $0.902 \pm 0.020$ & $1.153 \pm 0.032^{*}$ \\
& IGF-IR & $0.626 \pm 0.015$ & $0.927 \pm 0.031^{* *}$ \\
\hline
\end{tabular}

$* \mathrm{P}<0.05, * * \mathrm{P}<0.01$ compared with control

a)

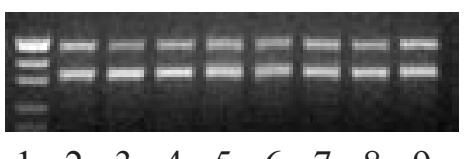

$\begin{array}{lllllllll}1 & 2 & 3 & 4 & 5 & 6 & 7 & 8 & 9\end{array}$ b)

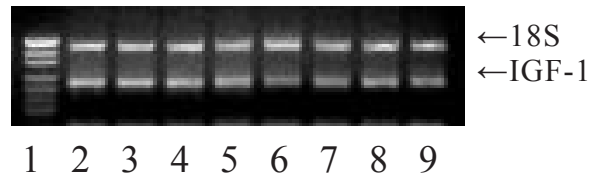

Figure 1. Representative electrophoresis showing the effect of rpGH on hepatic GH-R (a) and IGFI (b) mRNA expression in the pig. Lane 1: DNA marker PUC19, Lanes 2-5: rpGH treatment group, lanes 6-9: control group

\section{GH-R and IGF-I gene expression in LD muscle}

No marked changes of relative abundance of GH-R and IGF-I mRNA in LD muscle between GH-treated group and control group were observed. However, in ST muscle, GH-R and IGF-1 mRNA were significantly up regulated by 21.29 $(\mathrm{P}<0.05)$ and $41.04 \%(\mathrm{P}<0.01)$, respectively (Table 3$)$. 
Tissue IGF-1 content in liver, longissimus dorsi and semitendinosus muscles

rpGH administration increased concentration of IGF-I in liver, LD and ST muscle by 2.97 -fold $(\mathrm{P}<0.01), 2.93$-fold $(\mathrm{P}<0.01)$ and 5.53-fold, respectively $(\mathrm{P}<0.05$; Figure 2).

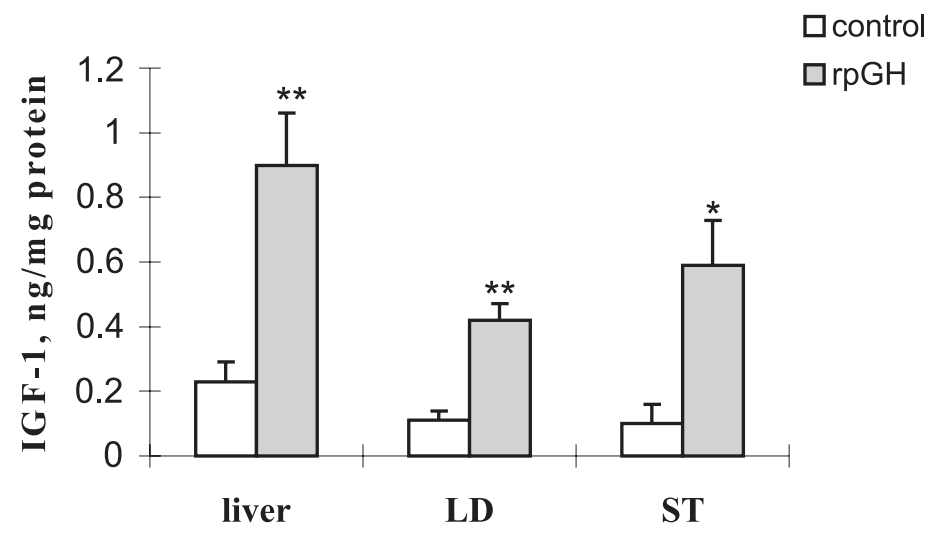

Figure 2. Effect of rpGH administration on content of IGF-I in liver, longissimus muscle (LD) and semitendinosus $(\mathrm{ST})$ muscles. ${ }^{*} \mathrm{P}<0.05, * * \mathrm{P}<0.01$ compared with control group

GH-R, IGF-1, IGF-IR and leptin mRNA expression in adipose tissue

Administration of rpGH up-regulated GH-R and IGF-1 mRNA expression by $50.66(\mathrm{P}<0.05)$ and $27.83 \%(\mathrm{P}<0.05)$, respectively. IGF-IR mRNA expression in adipose tissue was augmented by $48.08 \%(\mathrm{P}<0.01)$, whereas the relative abundance of leptin mRNA was reduced by $28.19 \%(\mathrm{P}<0.05)$ in adipose tissue (Table 3$)$.

\section{DISCUSSION}

Two pathways have been suggested to be involved in the growth promoting action of GH (Etherton and Bauman, 1998). One is through the mediation of endocrine IGF-I produced mainly in the liver and secreted into circulation (Florini et al., 1996), the other is through the autocrine or paracrine functions of IGF-I produced locally in extra-hepatic tissues. It was commonly accepted that GH exerts its growth-promoting function mainly via the first pathway. However, recent results gleaned from a liver-specific IGF-I knockout mouse model, in which 75\% decrease of circulating IGF-I did not affect growth rate (Siogren, 1999; Yakar, 1999; Roith et al., 2001) aroused a debate upon the function of endocrine IGF-I (Floria 
et al., 2001). In present study, the growth-promoting effect of rpGH was accompanied with significantly increased circulating IGF-I level, which seems to be mostly contributed by GH-R mediated upregulation of IGF-I mRNA expression in liver. This result suggests that the endocrine pathway of GH action could not be completely ruled out.

The previous reports regarding effects of GH on IGF-I mRNA in skeletal muscles were inconsistent. Both increase (Brameld et al., 1996, Lewis et al., 2000) and no change (Grant et al., 1991; Coleman et al., 1994; Brameld et al., 1996; Dunaiski et al., 1999) of IGF-I mRNA in skeletal muscles responding to GH administration have been reported. In our experiment, expression of IGF-I mRNA was found to be GH responsive in ST but not in LD muscle. But the IGF-I content was dramatically boosted up both in ST (5.53-fold) and to a lesser extent in LD muscle (2.93-fold). This indicates that muscle IGF-I expression can be regulated at the level of transcription and/or post-transcription by exogenous $\mathrm{GH}$ administration.

The effect of GH on adipose tissue has been investigated extensively both in vivo (Chung et al., 1985, Campbell et al., 1989) and in vitro (Boone et al., 1999; Gerfault et al., 1999). GH reduces adiposity through inhibition of lipogenesis and stimulation of lipolysis. Both preadipocytes and mature adipocytes possess GH-R, but expression of GH-R mRNA in adipose tissue was not responding to $\mathrm{GH}$ treatment (Brameld et al., 1996). In contrast, however, we observed a marked increase of GH-R mRNA in subcutaneous adipose tissue with rpGH treatment. Since both experiments were carried out in the pig of the same genetic background, this discrepancy could not be explained by species specificity. The possible explanation can be the length of GH administration ( 28 vs 7 d), the method for detecting the mRNA (RT-PCR vs RNase protection assay) or the animal condition (castrated vs intact).

Regarding the role of IGF-1 on metabolism of adipose tissue, there are some controversial results. Administration of IGF-1 in peripubertal Meishan barrows for 28 days failed to show significant changes in growth and carcass measures compared to controls, in spite of a $60 \%$ increase in serum concentrations of IGF-1 resulted from IGF-1 administration. Furthermore, the effect of IGF-1 and pGH in combination on back fat thickness was inferior to that of pGH alone (Klindt et al., 1998), suggesting that the effect of GH on adipose tissue is not mediated by IGF-1. However, administration of pGH significantly increased IGF-1 abundance in subcutaneous adipose tissue of growing pigs (Coleman et al., 1994; Brameld et al., 1996). The IGF-1 mRNA expression in white adipose tissue of rats was found to be very high, far above the levels in other tissues and comparable to that in liver, the major source of serum IGF-1 (Peter et al., 1993). Taking together the evidences that IGF-I is able to affect the proliferation of preadipocytes in vitro (Gerfault et al., 1999; Hausman et al., 2001), it is suggested that locally produced IGF-I, rather than circulating IGF-I, plays a crucial role in adiposity. In present study, we 
found significant increase in the expression of IGF-I and IGF-IR mRNA accompanying the marked up-regulation of GH-R mRNA in adipose tissue. This result suggest that signal relay pathway of GH-R/IGF-I/IGF-IR system for GH action is functional locally in adipose tissue, all these genes respond proportionally to $\mathrm{GH}$ administration to mediate the effect of GH on adiposity. The current study is the first to show the IGF-IR mRNA expression in adipose tissue up-regulated by rpGH treatment and also the first to exhibit the coordinated response of these target genes for $\mathrm{GH}$ action to $\mathrm{GH}$ administration in adipose tissues.

The available reports on the effects of exogenous $\mathrm{GH}$ on leptin expression and secretion are conflicting. Isozaki et al. (1999) reported an inhibitory effect on leptin mRNA level in visceral but not subcutaneous fat of the rat, while Housknecht et al. (2000) found that young castrated male cattle treated with bovine GH showed increased level of adipose tissue leptin mRNA, but incubation of subcutaneous adipose tissue explants for $24 \mathrm{~h}$ with $\mathrm{GH}$ had no effect on bovine leptin gene expression. Broiler chickens infused with recombinant chicken GH displayed a dose-dependant increase in liver leptin gene expression, whereas leptin expression in adipose tissue was unchanged (Ashwell et al., 1999). In this study, we observed that administration of rpGH for 28 days remarkably reduced serum leptin level and leptin gene expression in subcutaneous adipose tissue of growing pigs, which is in agreement with the finding of Spurlock et al. (1998) that acute GH administration significantly reduces leptin mRNA abundance of porcine. The down-regulation of leptin expression in adipose tissue could be a direct effect of GH or mediated via IGF-I/IGF-IR system, since this decrease was accompanied by the up-regulation of GHR, IGF-I and IGF-IR mRNA as observed in the present study.

\section{CONCLUSIONS}

The present study provides evidence that GH/IGF-I pathway is involved in both systemic and local effect of IGF-I in growth regulation. The enhanced hepatic IGF-I expression and serum IGF-I level by rpGH administration represent the systemic function in an endocrine manner, while the increased local production of IGF-I in muscle and adopise tissue suggest an functional GH/IGF-I pathway involved in paracrine/autocrine function. GH can act both at the level of transcription and/or post-transcription to regulate IGF-I expression in muscle. The coordinated changes of GHR, IGF-I, IGF-IR and leptin mRNA expression in adipose tissue indicate that the local IGF-I/IGF-IR system may mediate the effect of rpGH on leptin expression. 


\section{REFERENCES}

Ashwell C.M., McMurtry J.P., Wang X.H., Zhou Y., Vasilatos-Younken R., 1999. Effects of growth hormone and pair-feeding on leptin mRNA expression in liver and adipose tissue. Domest. Anim. Endocrinol. 17, 77-84

Boone C., Gregoire F., Remacle C., 1999. Regulation of porcine adipogenesis in vitro, as compared with other species. Domest. Anim. Endocrinol. 17, 257-267

Bradford M.M., 1976. A rapid and sensitive for the quantitation of microgram quantitites of protein utilizing the principle of protein-dye binding. Anal. Biochem. 72, 248-254

Brameld J.M., Atkinson J.L., Saunders J.C., Pell J.M., Buttery P.J., Gilmour R.S., 1996. Effects of growth hormone administration and dietary protein intake on insulin-like growth factor I and growth hormone receptor mRNA expression in porcine liver, skeletal muscle, and adipose tissue. J. Anim. Sci. 74, 1832-1841

Campbell R.G., Steele N.C., Caperna T.J., McMurtry J.P., Solomon M.B., Mitchell A.D., 1989. Effects of exogenous porcine growth hormone administration between 30 and 60 kilograms on the subsequent and overall performance of pigs grown to 90 kilograms. J. Anim. Sci. 67, 1265-1271

Chomczynski P., Sacchi N., 1987. Single-step method of RNA isolation by acid guanidinium thiocyanate-phenol-chloroform extraction. Anal. Biochem. 162, 156-159

Chung C.S., Etherton T.D., Wiggins J.P., 1985. Stimulation of swine growth by porcine growth hormone. J. Anim. Sci. 60,118-130

Coleman M.E., Russell L., Etherton T.D., 1994. Porcine somatotropin (pST) increases IGF-I mRNA abundance in liver and subcutaneous adipose tissue but not in skeletal muscle of growing pigs. J. Anim. Sci. 72, 918-924

Dunaiski V., Dunshea F.R., Walton P.E., Goddard C., 1999. Effect of growth hormone administration on IGF binding protein-3 mRNA levels in porcine tissues. J. Molecular Endocrinol. 22, 261-272

Etherton T.D., 2000. The biology of somatotropin in adipose tissue growth and nutrient partitioning. J. Nutr. 130, 2623-2625

Etherton T.D., Bauman D.E., 1998. Biology of somatotropin in growth and lactation of domestic animals. Physiol. Rev. 78, 745-761

Floria L, Terwilliger J.D., Lee K., 2001. Role of growth hormone and insulin-like growth factor 1 in mouse postnatal growth. Develop. Biol. 229, 141-162

Florini J.R., Ewton D.Z., Coolican S.A., 1996. Growth hormone and the insulin-like growth factor system in myogenesis. Endocr. Rev. 17,481-517

Gerfault V., Louveau I., Mourot J., 1999. The effect of GH and IGF-I on preadipocytes from Large White and Meishan pigs in primary culture. Gen. Comp. Endocrinol. 114, 396-404

Grant A.L., Helferich W.G., Kramer S.A., Merkel R.A., Bergen W.G., 1991. Administration of growth hormone to pig alters the relative amount of insulin-like factor-I mRNA in liver and skeletal muscle. J. Endocrinol. 130, 331-338

Hausman D.B., DiGirolamo M., Bartness T.J., Hausman Gj., Martin R.J., 2001 The biology of white adipocyte proliferation. Obes. Rev. 2, 239-254

Houseknecht K.L., Portocarrero C.P., Ji S., Lemenager R., Spurlock M.E., 2000. Growth hormone regulates leptin gene expression in bovine adipose tissue: correlation with adipose IGF-1 expression. J. Endocrinol. 164, 51-57

Isozaki O., Tsushima T., Miyakawa M., Nozoe Y., Demura H., Seki H., 1999. Growth hormone directly inhibits leptin gene expression in visceral fat tissue in fatty Zucker rats. J. Endocrinol. $161,511-516$

Klindt J., Yen J.T., Buonomo F.C., Roberts A.J., Wise T., 1998. Growth, body composition, and endocrine responses to chronic administration of insulin-like growth factor 1 and (or) porcine growth hormone in pigs. J. Anim. Sci. 76, 2368-2381

Lewis A.J., Wester T.J., Burrin D.G., Dauncey M.J., 2000. Exogenous growth hormone induces somatotrophic gene expression in neonatal liver and skeletal muscle. Amer. J. Physiol.-Regul. Integr. C 278, R838-R844 
Liu G.T., Chen W.H., Zheng Y.L., Chen J., Han Z.K., 1999. Development of a radiommunoassay for insulin-like growth factor 1. J. Nanjing Agr. Univ. 22, 63-66

NRC (National Research Council), 1998. Nutrient Requirements of Domestic Animal. Nutrient Requirement of Pigs. $9^{\text {th }}$ Edition. National Academy of Science, Washington, DC

Peter M.A., Winterhalter K.H., Boni-Schnetzler M., Froesch E.R., Zapf J., 1993. Regulation of insulin-like growth factor-I (IGF-I) and IGF-binding proteins by growth hormone in rat white adipose tissue. Endocrinology 133, 2624-2631

Roith D.L., Scavo L., Butle A., 2001. What is the role of circulating IGF-I? Trend Endocrinol. Metab. $12,48-52$

Siogren K., 1999. Liver-derived insulin-like growth factor (IGF-I) is the principal source of IGF-I in blood but is not required for postnatal body growth in mice. Proc. Natl. Acad. Sci. USA 96, 7088-7092

Spurlock M.E., Ranalletta M.A., Cornelius S.G., Frank G.R., Willis G.M., Ji S., Grant A.L., Bidwell C.A., 1998. Leptin expression in porcine adipose tissue is not increased by endotoxin but is reduced by growth hormone. J. Interferon Cytokine Res. 18, 1051-1058

Wauters M., Robert V.C., Luc F.V.G., 2000. Human leptin: from an adipocyte hormone to an endocrine metiator. Eur. J. Endocrinol. 143, 293-311

Yakar S., 1999. Normal growth and development in the absence of hepatic insulin-like growth factor I. Proc. Natl. Acad. Sci. USA 96, 7524-7529

\section{STRESZCZENIE}

Wpływ stymulacji rpGH na specyficzną tkankowo ekspresję genów zależnych od hormonu wzrostu u świń

Wieprzki świni wielka biała x landrace przez 28 dni otrzymywały domięśniowo iniekcje rekombinowanego świńskiego hormonu wzrostu (rpGH w dawce $4 \mathrm{mg} / \mathrm{dzień}, \mathrm{n}=8$ ) lub iniekcje soli fizjologicznej $(n=8)$. Cztery godziny po ostatniej iniekcji zwierzęta ubito, pobierając krew do analiz RIA oraz tkanki do analiz poziomu mRNA metodą półilościowego RT-PCR. Stwierdzono, że rpGH podwyższył zarówno średni dzienny przyrost masy ciała $(26,07 \%$; $<0,05)$, jak i stężenie osoczowego IGF-1 (70,94\%; P<0,05), obniżając jednocześnie stężenie leptyny w osoczu $(34,52 \%$; $<0,01)$. Poziom mRNA dla receptora GH (GH-R) wzrósł w wątrobie $(50,66 \%)$, tkance thuszczowej $(21,29 \%$; $\mathrm{P}<0,05)$ i mięśniu półścięgnistym (ST, 24,45\%; $\mathrm{P}<0,05)$, nie uległ natomiast zmianie w mięśniu najdłuższym grzbietu (LD). Jednocześnie stwierdzono podwyższoną ekspresję IGF-1 mRNA w wątrobie $(45,30 ; \mathrm{P}<0,05)$, w tkance thuszczowej $(27,82 \% ; \mathrm{P}<0,05)$ oraz w mięśniu ST $(41,04 \%$; $<<0,05)$, czemu towarzyszył blisko trzykrotny $(2,97 x)$ wzrost zawartości IGF-1 w wątrobie, ponad pięciokrotne $(5,53 x)$ jego zwiększenie w mięśniu ST oraz znaczący $(2,93 x)$ wzrost zawartości IGF-1 w mięśniu LD, w którym nie stwierdzono jednak istotnych zmian w poziomie IGF-1 mRNA. Ponadto, w tkance tłuszczowej egzogenny rpGH spowodował jednocześnie podwyższenie ekspresji genu dla receptora IGF-1( IGF-1R mRNA), $(48,08 \%$; P<0,01) i obniżenie poziomu mRNA dla leptyny.

Uzyskane wyniki wskazują, że działanie rpGH na ekspresję genów dla GH-R i IGF-1 jest specyficzne tkankowo, oraz że obniżające działanie rpGH na ekspresję genu dla leptyny może odbywać się zarówno bezpośrednio jak i pośrednio przy udziale lokalnego systemu IGF-1/IGF-1R. 